arsenite. ${ }^{1}$ This higher percentage of the fatty acid, however, shows that butyric acid has a stronger tendency to replace arsenious acid in the zinc as well as in the copper compounds.

In conclusion, I would express my obligations to $\mathrm{F}$. O. Woodruff for his carefully prepared bibliography which he placed at my disposal and to R. Corr and Fred Upson, of this laboratory, without whose careful work in preparing and analyzing compounds, only a small part of which are given here, this work could not have been brought to completion.

THE LNIVERSITY OF NEBRASKA.

\title{
A NEW ANALYSIS OF THE WATER OF OWENS LAKE, CALIFORNIA.
}

By C. H. Stone and F. M. Eatox.

Received June 30, Igo6.

In the eastern part of California between the White Mountain and Sierra Nevada Ranges, is a V-shaped depression, known as Owens Valley. Measured from crest to crest of the confining mountains, the valley is ro to 25 miles wide and 125 miles long. The lowest part of the depression is occupied by a saline body of water called Owens Lake. This was originally described as having an area of about I Io square miles, with an average depth of 9 feet ro inches. The only forms of life inhabiting the water are infusoria, alkali shrimps and the larvae of the alkali flies. There is no outlet, but the lake is fed by the Owens River and a number of small streams, practically all of which enter the valley from the Sierra side. While in the earlier reports it was stated that the loss by evaporation was very nearly counterbalanced by the inflowing water, evidences are abundant to-day that the size of the lake is decreasing. Mr. W. T. Lee, geologist of the U. S. Geological Survey, says in one of his recent bulletins: "The density of the water has increased to a point where sodium bicarbonate precipitates during the winter months without concentration by evaporation. From 1884 to 1894 , the lake surface remained practically stationary; from I 894 to 1904 the surface has lowered 16 feet, decreasing the length of the lake by five miles and the width by about two miles."

Owens Lake is probably the largest natural soda deposit in the world. Thirty years ago, Loew estimated that it contained

1 Bloxam: J. Chem. Soc. 15, 296 (1862). 
$22,000,000$ tons of sodium carbonate. For the past twenty years, the Inyo Development Co. has had an extensive plant for the recovery of this soda at Keeler, so that the conditions have been under careful scrutiny for a long time. From time to time, partial analyses of this water have been made. A few are given below for comparison with our own work. To render such comparison easier they have all been recalculated into parts per million of the various ions. In so far as we know, all have been corrected for the specific gravity of the water.

ANAIYSES OF THE WATER OF OWENS LAKE, CALIFORNIA.

\begin{tabular}{|c|c|c|c|c|}
\hline \multirow[b]{2}{*}{ 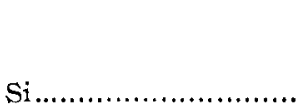 } & \multicolumn{4}{|c|}{ Parts per million. } \\
\hline & $\begin{array}{l}\text { A. } \\
76.5\end{array}$ & $\begin{array}{l}\text { B. } \\
96.8\end{array}$ & $\begin{array}{l}\text { c. } \\
984.0\end{array}$ & D. \\
\hline $\mathrm{Fe}, \ldots \ldots \ldots \ldots \ldots \ldots \ldots \ldots$ & & 9.2 & & \\
\hline $\mathrm{A} 1 \ldots \ldots \ldots \ldots \ldots \ldots \ldots \ldots$ & trace & 12.0 & & \\
\hline Ca........................ & trace & 13.2 & & \\
\hline $\mathrm{Mg} \ldots \ldots \ldots \ldots \ldots \ldots \ldots \ldots$ & trace & 4.7 & & \\
\hline $\mathrm{K} \ldots \ldots \ldots \ldots \ldots \ldots \ldots \ldots \ldots \ldots \ldots \ldots$ & 2750.6 & I 548.0 & I238.9 & \\
\hline $\mathrm{Na} \ldots \ldots \ldots \ldots \ldots \ldots \ldots \ldots$ & 21652.1 & 26835.6 & 39032.4 & 83 I 33.6 \\
\hline Li & trace & & & \\
\hline $\mathrm{SO}_{4}, \ldots \ldots \ldots \ldots \ldots \ldots \ldots \ldots \ldots \ldots \ldots \ldots \ldots \ldots$ & 936 I.7 & 7066.7 & $9525 \cdot 3$ & 20572.4 \\
\hline 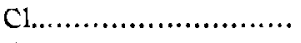 & I 3443.8 & I $82 \times 4.3$ & $255 \times 3.9$ & 56090.0 \\
\hline $\begin{array}{l}\mathrm{CO}_{9}, \ldots \ldots \ldots \ldots \ldots \\
\mathrm{PO}_{4} \ldots \ldots \ldots \ldots \ldots \ldots \ldots\end{array}$ & $\begin{array}{r}\text { I3I } 45.8 \\
\text { trace }\end{array}$ & I 8265.2 & 23573.9 & 52465.5 \\
\hline $\mathrm{B}_{4} \mathrm{O}_{7} \ldots \ldots \ldots \ldots \ldots \ldots \ldots \ldots$ & trace & 345.6 & & 4590.2 \\
\hline 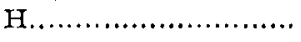 & & 59.3 & & 202.0 \\
\hline $\mathrm{NO}_{3}, \ldots \ldots \ldots \ldots \ldots \ldots \ldots$ & trace & & & \\
\hline Organic matter.......... & trace & & 242.2 & \\
\hline Total solids............ & 60430. & 7247 I. & IOOIII. & 217054 \\
\hline Sp. gr................. & $\mathrm{I} .05 \mathrm{I}$ & $1.062^{I}$ & & \\
\hline
\end{tabular}

"A."-Analysis by Oscar Loew, in I876. See U. S. G. S. 8th Annual Report, page 295 .

"B."-Analysis by T. M. Chatard, U. S. G. S., Bulletin 6o. Samples taken September 17, I886.

"C.".-See "Saline Deposits of California," State Mining Bureau Bulletin, No. 24, I902, page 95 .

"D."-Analysis by N. Wrinkle, Manager of the Inyo Development Company's Works, at Keeler, Ca1. Sample taken July, Igo4.

The sample which we analyzed was collected by Mr. N. Wrinkle, superintendent of the Inyo Development Co., about 2,000 feet from the shore of the lake and at a depth of about 5 feet. As the

1 At $25^{\circ} \mathrm{C}$. 
methods applied were necessarily different from those ordinarily used in water analysis, we have thought that a short description of them might be of interest.

Considering the small amounts of calcium, magnesium, phosphates, etc., shown in the above analyses, one's first thought naturally is that a large amount of the water must be evaporated in order to obtain enough of these substances to work with. But a second thought will show the futility of this for the water is already saturated and the evaporation of a large quantity is not only a difficult matter on account of the crust which forms over the surface of the liquid almost as soon as the dish touches the steam-bath, but also undesirable because of the enormous anount of salt to be handled. Therefore it was found desirable to follow the procedure of Mr. T. M. Chatard in his excellent study of this lake in 1886 , and work on portions of $50 \mathrm{cc}$. to $100 \mathrm{cc}$. The specific gravity was found by the pycnometer method, each of us making the determination independently and arriving at identically the same result.

The question of total soluble salts was a troublesome one on account of the amount of water, both mechanically held and chemically combined, which must be expelled without driving off carbon dioxide. Being unable to secure an apparatus such as Chatard used we were obliged to devise a method of our own. Ten cc. of the water were evaporated to dryness in each of two platinum dishes; one of these was ignited at a low heat, weighed and the carbon dioxide in the residue determined gravimetrically. In the other, carbon dioxide was determined without previous ignition. Then having determined the carbon dioxide in the original water, it was easy to calculate the loss of the same due to evaporation and ignition. From these data the weight of the total solids with all water expelled may be derived.

We realize that this makes no allowance for organic matter, but this is negligible when compared with the weight of the solids found.

Another portion of Ioo cc. was acidified, evaporated to dryness, and the silica dehydrated, filtered off and weighed. In the filtrate the iron and the alumina were precipitated by ammonia, but on account of the presence of phosphates it seemed probable that these phosphates and also calcium would be found in the 
precipitate. Therefore we fused the latter with potassium acid sulphate and after solution determined the phosphoric acid, and tested for calcium with negative results. Deducting the weight of the phosphoric acid from the total weight of precipitate gave us the weight of the iron and alumina. In the filtrate from the ammonia precipitation the lime and magnesia were determined as usual.

In two other portions of $50 \mathrm{cc}$. each sulphuric acid was determined as barium sulphate and in the filtrate from this the total alkalies were determined in the usual way, using milk of lime and ammonium carbonate. In one of these the potash was determined with chlorplatinic acid. From the other, lithitum was extracted with amyl alcohol according to the method of Gooch and Whitfield (Bull. 47 , U. S. G. S.). Two such separations were made in order to insure the complete extraction of the lithium and the proper correction was applied for the volume of amyl alcohol used. The lithium was then converted to sulphate and weighed. This residue contained whatever rubidium, caesium and thallium were present in the water and qualitative tests were made for. these according to methods given in Behren's "Microchemical Analysis." Phosphoric acid was determined in a separate portion of $50 \mathrm{cc}$. by precipitation with ammonium molybdate and finally with magnesia mixture, having first removed the arsenic with hydrogen sulphide. Carbon dioxide and chlorine were determined gravimetrically, the one by absorption in caustic potash and the other by precipitation with sliver nitrate.

We first endeavored to determine nitrates by the Sprengel method, having previously removed the chlorine with silver oxide, but found on adding the phenolsulphonic acid that red fumes of nitrous oxide were freely evolved. In view of the large amount of nitrate present we were obliged to resort to another method. Twenty-five cc. of the water were diluted to $200 \mathrm{cc}$, Io cc. of caustic suda added and the solution boiled until the volume was reduced to $7 \mathrm{o} \mathrm{cc}$. When cold, it was poured into a glass cylinder holding $120 \mathrm{cc}$, 20 sq. cm. of aluminum foil added and the mouth of the cylinder closed with a cork bearing a small tube filled with pumice moistened with hydrochloric acid. After standing several hours, the contents of the tube were transferred to a retort, caustic potash added and the ammonia distilled off and determined by titration. 
Without expecting any particular results, hydrogen sulphide was passed into a portion of the water heated to boiling. To our surprise, a considerable yellow precipitate formed, and on examining this by the Marsh test it was found to be arsenic. This was then determined quantitatively in Ioo cc. of the water by precipitation with hydrogen sulphide and finally with magnesia mixture. Every reagent used was tested for arsenic and several blanks were run, so that there is no reasonable room for doubt that the arsenic came from the water itself.

After attempting to determine the boric acid by the methods of Marignac and of Gooch, and having poor success with the former on account of the amount of salt in the water, and with the latter because of the difficulty in removing the chlorine, we finally adopted the following method: roo cc. of the water were placed in a large Florence flask with $300-400 \mathrm{cc}$. of distilled water, the boric acid liberated by hydrochloric acid and then the flask was connected to a condenser and steam blown through it. In this way the boric acid was distilled over with the steam free from everything but hydrochloric acid and was received in a solution of caustic potash. A test made at the end of the operation showed that all the boric acid had passed over into the potash solution. Now the solution in the receiver, containing only potassium borate, potassium chloride and potassium hydroxide, was treated exactly as in Stromeyer's process save that Fresenius' modification for removing the silica was adopted.

The results of the analysis are given in the following table; all are expressed in parts per million, and are corrected for the specific gravity of the water.

Duplicates were run on all the determinations except lithium and boron, and the results checking very closely in all cases, they have been averaged for this table. The iron and alumina were calculated as alumina because of the small amount of the precipitate which seemed to be iron. The bicarbonates were determined by titration with sodium acid sulphate and found to be $772 \mathrm{I}$ parts, calculated as $\mathrm{HCO}_{3}$. 


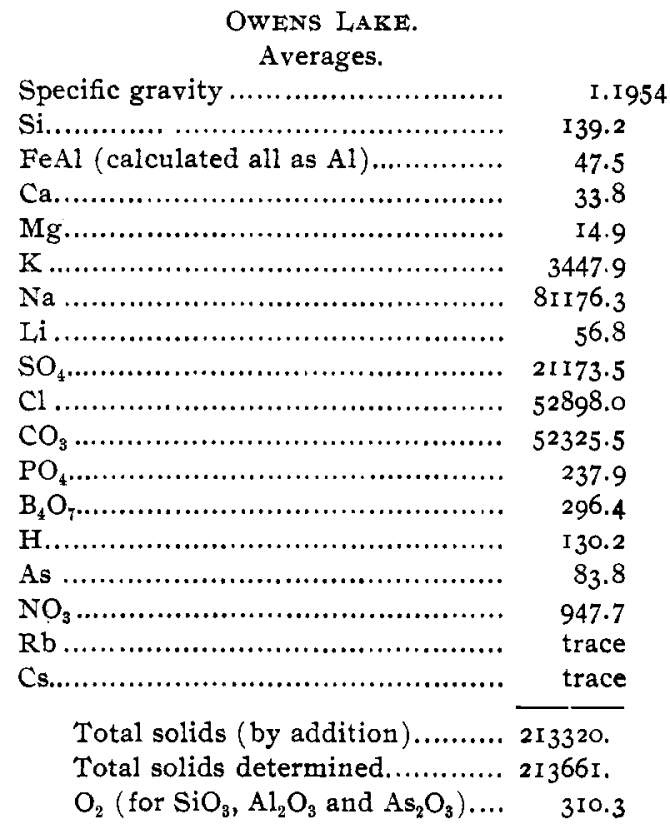

As will be seen from the table, sodium and potassium carbonates, chlorides and sulphates constitute by far the major part of the salts present in the water. The large amount of sulphate is important because this is the most troublesome salt to a manufacturer of soda. The arsenic is a curious and rather unexpected feature, for while it is often present in ground waters it is, we believe, seldom a constituent of surface waters. In this case it very probably arises from the decomposition of arsenopyrite. The amount of phosphate is another interesting feature; in previous analyses of water of the lake this has been reported simply as trace and in the majority of water analyses it is not determined at all. There are, we believe, few water analyses on record where the amount of phosphate reported is as great as in Owens Lake. Another noteworthy determination is that of nitrates. ' Of course the amount here reported may be exceeded in a few cases where the water percolates through nitrate beds, but this figure has rarely if ever been reached by a surface water. The carbonate is the feature of greatest commercial interest and is the largest we have ever found in a natural water, being over three times the amount present in the Big Soda Lake at Ragtown, 
Nevada. It may be of interest to compare the chlorine found in Owens Lake with that present in various other saline waters. The average chlorine for the ocean is about igoo parts per I,000,000; Big Soda Lake has 40,000 parts; Great Salt Lake (in 1873) 73,000; Urmiah Lake, I20,000; Bogdo Lake, 160,000; Indevsk Lake, I60,000; Elton Lake, I70,000; the Dead Sea, in I864, a maximum of 170,000 ; and two salt springs in Oklahoma, recently examined by one of us, over 180,000 parts. Thus it will be seen that all the above-named waters, with the exception of the ocean and Big Soda Lake, have a higher chlorine content than Owens Lake, and exactly the same relation holds with regard to the total solids.

While no general conclusions can be drawn from the results of a single analysis, this one has at least shown that the water of Owens Lake is rapidly concentrating and at the present rate will soon reach the saturation point. It has also demonstrated the existence in determinable quantities of certain substances which have hitherto been neglected. We believe that if a similar analysis could be made, at regular intervals, of several of the inportant saline bodies of water, such as Great Salt Lake, Owens Lake, Soda Lake, etc., interesting and valuable data would be accumulated, and it is our hope to be able to undertake a small portion of such work in the near future.

U. S. Geological Strkver:

BERKELEY, CAL.

[CoNtribution from the Whlicome Chemical Research LaboraTORIES, LONDON.]

\section{CHEMICAL AND PHYSIOLOGICAL EXAMINATION OF THE FRUIT OF CHAILLETIA TOXICARIA. ${ }^{1}$}

(A WEST AFRICAN POISON.)

BY FREDERICK B. POWER AND FRANK TUTIN.

Received June I9, 1906.

THE present investigation of the fruit of Chailletia toxicaria, Don, was undertaken at the suggestion of Dr. W. Renner, Medical Officer, Colonial Hospital, Freetown, Sierra Leone, who also kindly provided us with the material for this purpose.

The interest which this subject possesses will be apparent from

1 Presented, in abstract, at the International Congress of Applied Chemistry, Rome, Italy, April, Igo6. 